This item was submitted to Loughborough's Research Repository by the author.

Items in Figshare are protected by copyright, with all rights reserved, unless otherwise indicated.

\title{
Editorial: 22nd European Conference on Fracture (ECF 22)
}

PLEASE CITE THE PUBLISHED VERSION

https://doi.org/10.1016/j.jifatigue.2020.105658

PUBLISHER

Elsevier

VERSION

AM (Accepted Manuscript)

PUBLISHER STATEMENT

This paper was accepted for publication in the journal International Journal of Fatigue and the definitive published version is available at https://doi.org/10.1016/j.ijfatigue.2020.105658

\section{LICENCE}

CC BY-NC-ND 4.0

\section{REPOSITORY RECORD}

Sedmak, Aleksandar, Francesco lacoviello, Vadim Silberschmidt, and Sigfried Schmauder. 2020. "Editorial: 22nd European Conference on Fracture (ECF 22)". Loughborough University. https://hdl.handle.net/2134/13242410.v1. 


\section{Editorial: 22nd European Conference on Fracture (ECF 22)}

This Virtual Special Issue (VSI) contains selected papers presented at the 22nd European Conference on Fracture (ECF 22) - Loading and Environment Effects on Structural Integrity, held in Belgrade, Serbia, August 26-31, 2018. A total of 563 participants from 47 countries took part in presenting 10 Plenary Lectures, 376 oral presentations and 122 posters. Proceedings have been published electronically, in a special edition of Procedia Structural Integrity in late 2018. High quality papers in their extended form have been considered for publishing in special issues of ESIS associated journals (WoS), including International Journal of Fatigue. In the scope of the main ECF22 topic - Loading and Environmental effects on Structural Integrity, separated into 4 major subtopics: Loading types (static and quasi-static, cyclic and very high cycle-loading; low cycle, vibrations, impact and earthquake), Environment (corrosion, high operating temperatures, hydrogen embrittlement), Structures (power plants, welded structures, civil engineering objects, transportation) and Materials (metallic materials, plastics, ceramics, composite materials, nanomaterials), large number of papers dealt directly or indirectly with fatigue, including minisymposium on "Defects and Fatigue". Other important topics involved Fatigue considerations of modern metallic and non-metallic materials, advances methods in fatigue analysis and fatigue lifetime and damage tolerance of structures subjected to cyclic loading. For the purpose of this special issue it was decided to cover two major topics under the common title: "Fatigue from crack initiation to failure: role of defects and life assessment".

In this scope following 17 papers are accepted for the VSI:

- Fracture mechanics and fatigue crack propagation in armor steel welds

- Effect of LCF on behaviour and microstructure of microalloyed HSLA steel and its simulated CGHAZ

- The investigation of the fatigue failure of passenger carriage draw- hook

- Fracture behavior of the secondary A226 cast alloy with $0.9 \% \mathrm{Fe}$

- Determination of the critical socket depths of 10.9 and 8.8 grade M8 DIN 912 fasteners

- Investigation of the brittle fracture of the locomotive draw hook

- Failure Analysis of Boiler Tube at a Petrochemical Plant

- Failure of ceramic coatings on cast and selective laser melted Co-Cr dental alloys under tensile test: Experiment and finite element analysis

- Butt welded joints assessment after fire exposure

- Non-destructive evaluation of brittle fracture resistance of operated gas pipeline steel using electrochemical fracture surface analysis

- Hydraulic turbines lifetime in terms of fracture mechanics

- Corrosion fatigue failure of steam turbine moving blades: case study

- Study of Disturbance Energy Absorption by the System under Uniaxial Cyclic Load

- Failure Behaviour of Short-fibre-reinforced PBT Composites: Effect of Strain Rate

- Integrity assessment and determination of residual fatigue life of vital parts of bucket-wheel excavator operating under dynamic loads

- Damage mechanism analysis of a high-strength dual-phase steel sheet with optimized fracture samples for various stress states and loading rates

- The fatigue strength of bidirectionally bent steel cord used in tyres

Guest Editors

Aleksandar Sedmak, Francesco Iacoviello, Vadim Silberschmidt, Sigfried Schmauder 